\title{
Correction to: Herd concentration areas create greenhouse gas hotspots
}

\author{
Elaine Mitchell (1) - Daniele De Rosa $\cdot$ Peter Grace $\cdot$ David Rowlings
}

Published online: 16 August 2021

(C) The Author(s), under exclusive licence to Springer Nature B.V. 2021

Correction to: Nutr Cycl Agroecosyst

https://doi.org/10.1007/s10705-021-10159-0

In the original publication of the article Figs. 1, 2 and 3 were incorrectly displayed. These have been corrected with this Correction as below:

The original articles can be found online at https:// doi.org/10.1007/s10705-021-10159-0.

E. Mitchell $(\bowtie) \cdot$ D. De Rosa · P. Grace · D. Rowlings Centre for Agriculture and the Bioeconomy, Queensland University of Technology, Brisbane, QLD, Australia

e-mail: e5.mitchell@qut.edu.au 


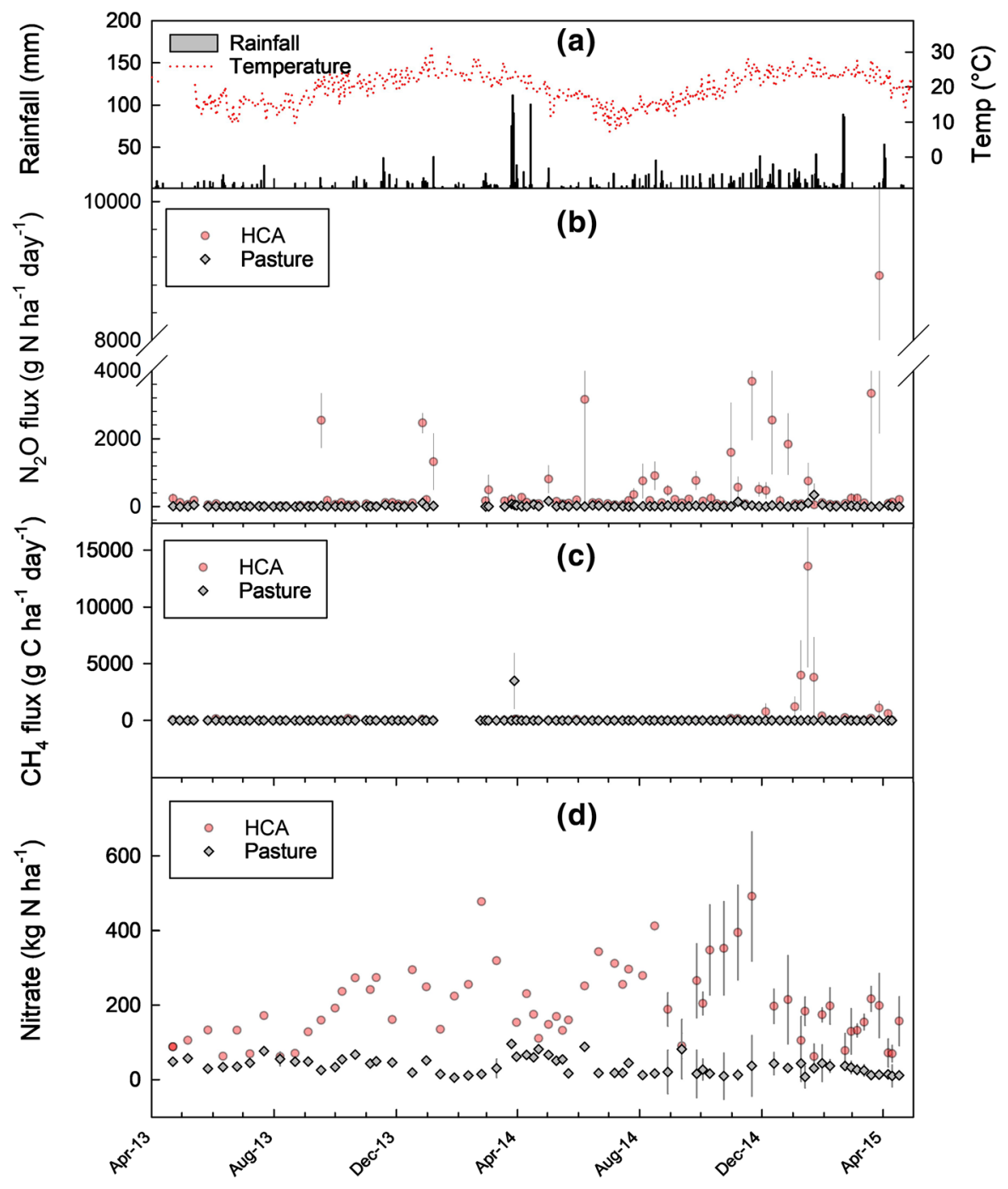

Fig. 1 a Daily rainfall and mean air temperature for the experimental period at Gympie (April 2013-April 2015). b Daily mean $\mathrm{N}_{2} \mathrm{O}$ flux $\left(\mathrm{g} \mathrm{N} \mathrm{ha}^{-1}\right.$ day $\left.^{-1}\right)$ for the HCAs and pasture land management areas. c Daily mean $\mathrm{CH}_{4}$ flux $\left(\mathrm{g} \mathrm{CH}_{4}-\right.$
$\left.\mathrm{C} \mathrm{ha}{ }^{-1} \mathrm{day}^{-1}\right)$. d Soil mineral nitrate content $\left(\mathrm{NO}_{3}{ }^{-}\right)(\mathrm{kg} \mathrm{N}$ $\left.\mathrm{ha}^{-1}\right)(0-10 \mathrm{~cm})$ for the HCAs and pasture land management areas 


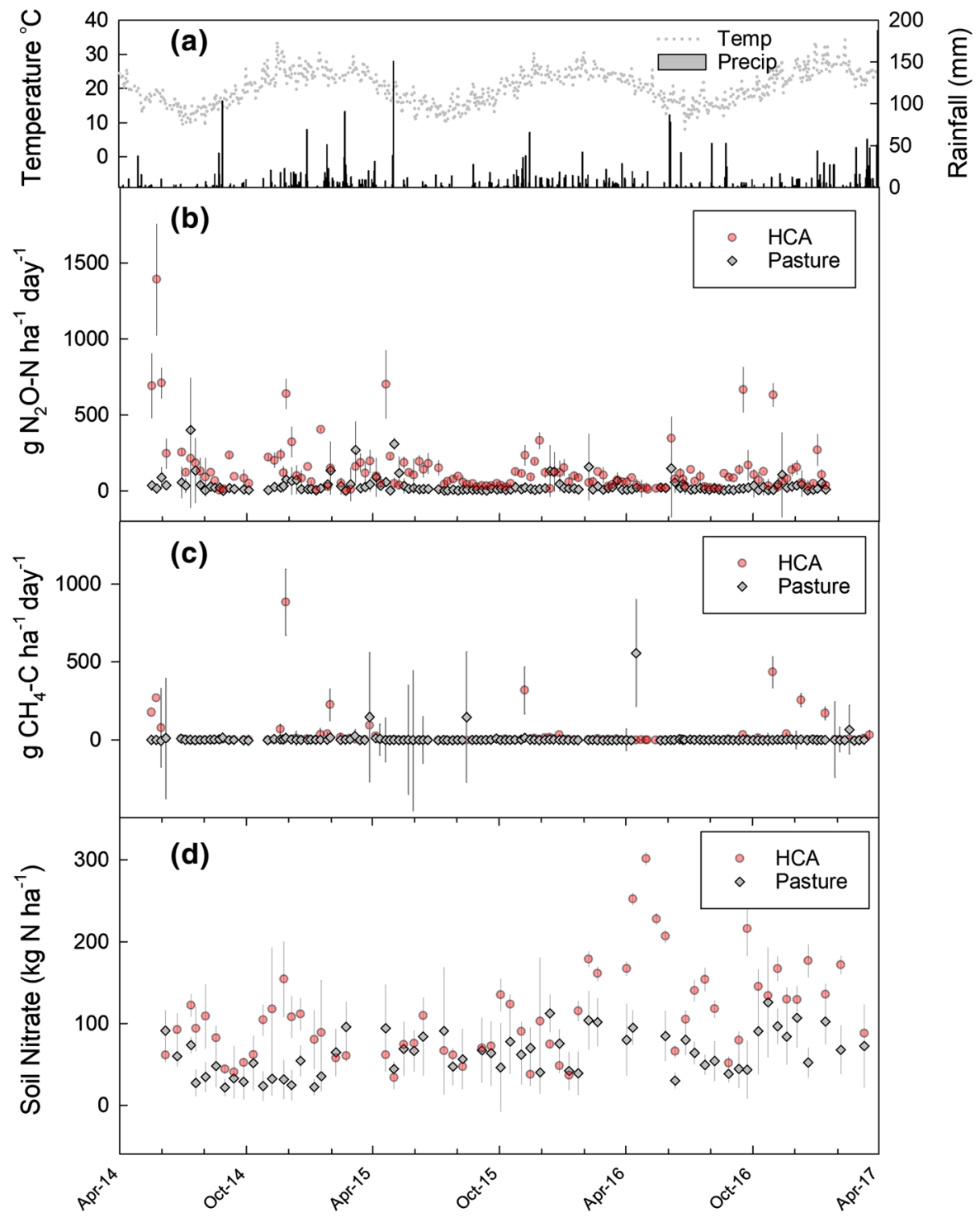

Fig. 2 a Daily rainfall and mean air temperature for the experimental period at Casino (June 2014-March 2017). b Daily mean $\mathrm{N}_{2} \mathrm{O}$ flux $\left(\mathrm{g} \mathrm{N} \mathrm{ha}^{-1}\right.$ day $^{-1}$ ) for the HCAs and pasture land management areas. c Daily mean $\mathrm{CH}_{4}$ flux $\left(\mathrm{g} \mathrm{CH}_{4}-\mathrm{C}\right.$ ha ${ }^{-1}-$ day $\left.^{-1}\right)$, and $\mathbf{d}$ soil mineral nitrate content $\left(\mathrm{NO}_{3}{ }^{-}\right)(0-10 \mathrm{~cm})$ for the HCAs and pasture land management areas 


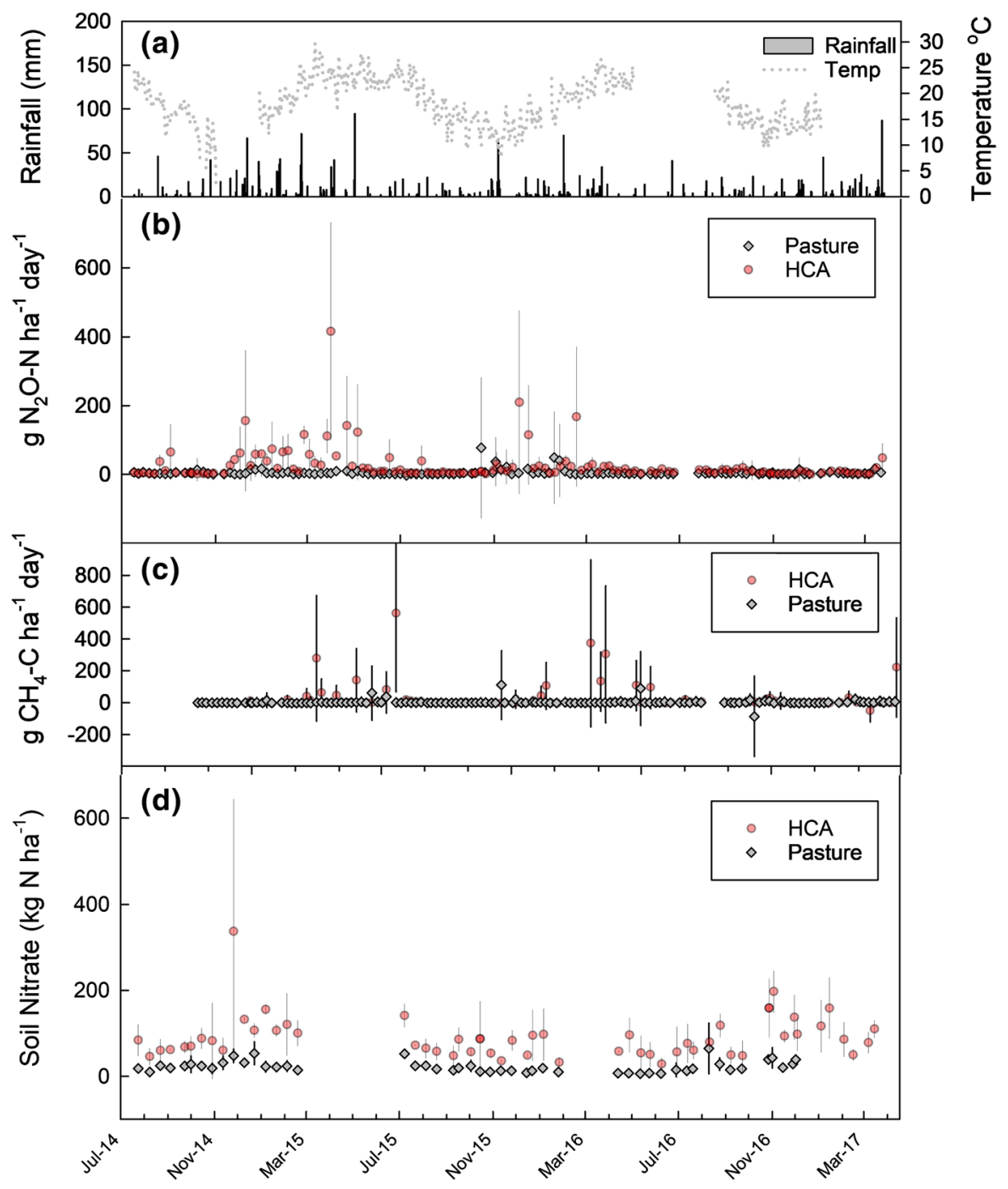

Fig. 3 a Daily rainfall and mean air temperature for the experimental period at Kerry (June 2014-March 2017). b Daily mean $\mathrm{N}_{2} \mathrm{O}$ flux $\left(\mathrm{g} \mathrm{N} \mathrm{ha}^{-1}\right.$ day $^{-1}$ ) for the HCAs and pasture land management areas. c Daily mean $\mathrm{CH}_{4}$ flux $\left(\mathrm{g} \mathrm{CH}_{4}-\mathrm{C}\right.$ ha ${ }^{-1}-$ day $\left.{ }^{-1}\right)$, and $\mathbf{d}$ Soil mineral nitrate content $\left(\mathrm{NO}_{3}{ }^{-}\right)(0-10 \mathrm{~cm})$ for the HCAs and pasture land management areas

Publisher's Note Springer Nature remains neutral with regard to jurisdictional claims in published maps and institutional affiliations. 